\title{
Sodium Silicate Cold-Bonded Chromite Pellets for the Ferrochromium Industry - Identifying a Suitable Process
}

\author{
S.P. du Preez ${ }^{a} *$ (1), Z. Maree $^{a}$ (1), J.P. Beukes ${ }^{a}$ \\ ${ }^{a}$ North-West University, Faculty of Natural and Agricultural Sciences, Chemical Resource Beneficiation \\ (CRB), Private Bag X6001, Potchefstroom, 2520, South-Africa
}

Received: June 5, 2020; Revised: July 27, 2020; Accepted: August 4, 2020

\begin{abstract}
Chromite fines (defined as particles smaller than $6 \mathrm{~mm}$ ) account for a significant fraction of mined South African chromite ore. These fines are pelletized to allow safe furnace smelting conditions. However, pelletization is an energy- and cost-intensive process that requires significant capital investment and has high operational costs as continuous curing temperatures of $1300-1500{ }^{\circ} \mathrm{C}$ are required. In this study, various cold-bonded pelletization processes were investigated to identify a process to prepare cold-bonded chromite pellets. A feasible process was identified and developed to produce mechanically strong chromite pellets using $3 \mathrm{wt} \%$ sodium silicate- $3 \mathrm{wt} \% \mathrm{SiO}_{2}$ as the binder and $\mathrm{KOH}$ as an alkaline activator. The binding mechanism is based on the combined effects of sodium silicate and geopolymerization. It was determined that pellets cured at $75^{\circ} \mathrm{C}$ had compressive strengths of $2.41-3.12 \mathrm{kN}$. The mechanical strength of these cold-bonded pellets where similar to, or exceed that of pellets currently used in the $\mathrm{FeCr}$ industry.
\end{abstract}

Keywords: Chromite, Cold-bonded, Compressive strength, Ferrochrome/ferrochromium, Energy dependence.

\section{Introduction}

Chromite is the only economically viable source of virgin chromium units, belonging to a mineral group characterized by $\left[\left(\mathrm{Mg}, \mathrm{Fe}^{2+}\right)\left(\mathrm{Al}, \mathrm{Cr}, \mathrm{Fe}^{3+}\right)_{2} \mathrm{O}_{4}\right]^{1-3}$. The majority of chromite is carbothermically smelted in semi-closed or closed alternating current submerged arc furnaces (SAFs) or closed direct current (DC) arc furnaces to obtain a crude alloy between iron $(\mathrm{Fe})$ and $\mathrm{Cr}$ called ferrochrome $(\mathrm{FeCr})^{4,5}$. Approximately $80 \%$ of produced $\mathrm{FeCr}$ is consumed by the stainless steel industry ${ }^{6}$. Stainless steel is an essential modern-day alloy ${ }^{7}$, owning its corrosion resistance to the inclusion of $\mathrm{Cr}$, making $\mathrm{FeCr}$ equally important.

Mined chromite ore is often friable and typically contains varying fine $(<6 \mathrm{~mm})$ ore percentages ${ }^{8}$. South African ore, which is considered as the example ore is this study, is classified as friable and it is common to recover 10 to $15 \%$ lumpy ore ( 50 to $150 \mathrm{~mm}$ ), 8 to $12 \%$ pebble/chip ore (6 to $15 \mathrm{~mm}$ ), with the remaining ore in the fine fraction $(<6 \mathrm{~mm})^{4,9,10}$. Smelting of chromite fines is generally limited in semi-closed SAFs and restricted in closed SAF operations as it may result in bed sintering, which increases the risk of dangerous gas eruptions and bed turn-overs ${ }^{4,11,12}$. Closed direct current (DC) furnaces may accommodate exclusively fine feed. However, DC furnaces are not as widely applied as SAFs, with several such smelters currently operating in Kazakhstan and South Africa ${ }^{5}$. FeCr produced in semi-closed SAFs accounts for a substantial fraction of globally produced $\mathrm{FeCr}^{5,13}$.

To safely smelt chromite ore fines, a pelletization process is necessary. Fine clay binders (e.g. refined bentonite,

*e-mail: faan.duPreez@nwu.ac.za;

attapulgite) are typically used as a binder to generate pellets with sufficient green ("wet" pellets before curing procedures) and cured compressive strengths ${ }^{14}$. Green pellets are cured to render them physically suitable for smelting. Two pellet curing processes are utilized by the South African $\mathrm{FeCr}$ industry (and in fact, worldwide): (i) Oxidative sintering. Green pellets are introduced to a moving steel belt grate furnace (i.e. sintering furnace) and are placed on-top a layer of already sintered pellets to protect the under-laying steel sintering belt from excessive temperatures. Gas burners combusting carbon-based fuels are used to steadily increase the sintering temperature to between 1400 to $1500^{\circ} \mathrm{C}^{8}$. The pellets are then ignited by passing air through the pellet bed. The carbonaceous reductant present in the pellets (between 1 to $2 \%$ ) provide sufficient exothermic energy to allow pellets to sinter ${ }^{12,15,16}$. (ii) Pre-reduction (also known as solid-state reduction). This curing method is defined as a process where fractions of $\mathrm{Cr}$ and $\mathrm{Fe}$ present in the chromite spinel is either reduced to a lower oxidation state (e.g. $\mathrm{Fe}^{3+}$ reduces to $\mathrm{Fe}^{2+}$ ), or their metallic states (i.e. $\mathrm{Cr}^{3+}$ reduces to $\mathrm{Cr}^{0}$ and $\mathrm{Fe}^{2+}$ reduces to $\mathrm{Fe}^{0}$ ) during the curing process. This is achieved by adding approximately $13 \%$ carbonaceous reductant as a pellet constituent and by firing pre-dried green pellets in a counter current rotary kiln in a non-oxidizing atmosphere at a temperature of between 1300 to $1400{ }^{\circ} \mathrm{C}^{5,8,17}$.

Considering the high temperatures $\left(1300\right.$ to $1500{ }^{\circ} \mathrm{C}$ ) required during currently applied pellet curing processes, and the fact that these kilns combust carbon-based fuel sources to achieve these temperatures, it is understandable that these processes are energy-intensive, environmentally benign, and expensive to commission/operate. To alleviate 
some of the energy dependence of $\mathrm{FeCr}$ produces, an alternative pelletization process has to be developed. Such alternative approaches have been investigated in recent years. The use of ordinary Portland cement as a Fe ore binder has been considered and several such processes have been developed ${ }^{18-22}$. However, the use of cement as a pellet binder holds some disadvantages, e.g., 28 days curing period, $10 \mathrm{wt} \%$ minimum cement addition. Furthermore, cement is a low-temperature binder and can result in the reformation of fines as cement-bonded pellets are exposed to the furnace bed hot area, before reaching the smelting area. In addition to these practical limitations, anthropogenic hexavalent $\mathrm{Cr}$, i.e. $\mathrm{Cr}$ (VI), is a major environmental concern ${ }^{5,14,23-26}$. Cement contains significant amounts of alkali and alkali earth metals and will increase the total alkali content present in the furnace bed. When considering that during alkaline chromite roasting to produce sodium chromate $\left(\mathrm{Na}_{2} \mathrm{CrO}_{4}\right)$, the alkali and oxygen contents and the roasting temperature are major factors determining the $\mathrm{Na}_{2} \mathrm{CrO}_{4}$ formation efficiency ${ }^{27}$. Although the alkali and alkali earth metal content present in the feed material is a fraction of that present during alkaline chromite roasting, the aspects that promote $\mathrm{Cr}$ (III) to $\mathrm{Cr}$ (VI) oxidation are the same. The in-situ oxidation of $\mathrm{Cr}$ (III) is a major issue during semi-closed SAF operations, considering that CO-rich off-gas is combusted on-top of the furnace bed in a semi-oxidizing environment $t^{5,24,28}$. Thereafter, particulate matter present in the off-gas is removed in bag filter houses ${ }^{26}$. Gericke (2015) stated that the water-soluble Cr (VI) of bag filter dust (BFD) originating from semi-closed SAFs operating on acid and alkaline slag regimes were 1000 and $7000 \mu \mathrm{g} \mathrm{Cr}$ (VI)/g BFD. These values were 70 - 200 times higher than particulate matter originating from closed SAF off-gas (i.e. venturi sludge) ${ }^{28}$. Thus, the use of cement as a pellet binder will likely cause operation and environmental complications.

Organic pellet binders, e.g. corn starch, cellulose, wheat flour, molasses, dextrin, lactose monohydrate, have also received attention in recent years ${ }^{29-31}$. The use of organic binders is however perplexed by their low decomposition temperatures. During chromite smelting procedures, pellets are exposed to furnace bed temperatures of $>700{ }^{\circ} \mathrm{C}$ before reaching the hot zone $\left(2000-3000{ }^{\circ} \mathrm{C}\right)$ where chromite smelting occurs ${ }^{11}$. Organic binder decomposition will result in the reformation of chromite fines within the furnace bed, increasing the risk of bed sintering. In addition to this, the occurrence of pellet bursting is possible. Chromite pellets with too high volatile/moisture contents may burst when exposed to high temperatures, causing several operation complications ${ }^{17,32}$. Therefore, organic binders were not considered in this study.

Another relatively unexplored approach to prepare mechanically strong chromite pellets is the use of sodium silicate. Zambrano et al. ${ }^{33}$ prepared mechanically strong sodium silicate bonded chromite-composite pellets cured for $2 \mathrm{~h}$ between 900 to $1300^{\circ} \mathrm{C}$ in an argon atmosphere. As far as the authors could assess, and based on personal communications with various South African FeCr producers, a feasible process to produce chromite pellets at low temperatures has yet to be realized by industry. The main objective of this study was to identify a process to produce mechanically strong cold-bonded chromite pellets and to evaluate its real-world application in the ferrochrome industry.

\section{Materials and Methods}

\subsection{Materials and chemicals}

Metallurgical grade chromite ore, pre-reduced chromite pellets (produced from the latter ore), and BFD was collected from a large South African FeCr producer. Representative sample collection was performed as described in Du Preez et al. ${ }^{34}$. The metallurgical-grade ore was used as the chromite source throughout this study. Glastonbury et al. ${ }^{16}$ and Van Staden et al. ${ }^{35}$ presented the chemical analyses ( $\mathrm{wt} \%$, determined by ICP-OES) of the chromite ore and BFD, respectively. These characterizations are presented in Table 1.

All chemicals used were of an analytical grade. Sodium metasilicate $\left(\mathrm{Na}_{2} \mathrm{SiO}_{3}\right)$ was obtained from Sigma Aldrich and was used throughout this paper as the pellet binder. The sodium silicate used had total alkalinity $\left(\mathrm{Na}_{2} \mathrm{O}\right)$ and soluble silica $\left(\mathrm{SiO}_{2}\right)$ contents of 50.78 and $49.22 \mathrm{wt} \%$, respectively; yielding a mass ratio ( $\mathrm{wt} \% \mathrm{Na}_{2} \mathrm{O}$ to $\mathrm{wt} \% \mathrm{SiO}_{2}$ ) of 1.03 . Precipitated silicon dioxide $\left(\mathrm{SiO}_{2}\right)$ and sodium bicarbonate $\left(\mathrm{NaHCO}_{3}\right)$ were obtained from BDH laboratories and MINEMA, respectively. Aluminium oxide $\left(\mathrm{Al}_{2} \mathrm{O}_{3}\right)$ was obtained from Merck. Potassium hydroxide $(\mathrm{KOH})$ was obtained from Promark Chemicals. Technical grade carbon dioxide $\left(\mathrm{CO}_{2}\right)$ gas (99.0\% purity) was supplied by Afrox (South Africa).

\subsection{Green pellet generation}

In industry, green pellets are prepared using clay as the binder and the clay addition is dictated by the subsequent curing process. For instance, green pellets intended for oxidative sintering or pre-reduction typically contain 1 to $2 \mathrm{wt} \%$ or 3 to $4.5 \mathrm{wt} \%$ clay binder, respectively ${ }^{8}$. Here, clay binders are substituted by sodium silicate. The foundry industry is referred to for sodium silicate addition selection; 3 to $5 \mathrm{wt} \%$ sodium silicate is typically used to prepare sandbased refractory moulds ${ }^{36}$. Considering this, a relatively conservative approach was taken and a $3 \mathrm{wt} \%$ sodium silicate addition was used to prepare pellets. Furthermore, carbonaceous materials are typically included in industrial pellets destined for thermal curing to serve specific goals, i.e. provide exothermic energy to enable pellet sintering during oxidative sintering, or to reduce the oxidation state/metallize

Table 1. Chemical analyses (wt $\%$ ) of the obtained chromite ore ${ }^{16}$ and $\mathrm{BFD}^{35}$ as determined by ICP-OES.

\begin{tabular}{ccc}
\hline Compound & Chromite ore & BFD \\
\hline $\mathrm{Cr}_{2} \mathrm{O}_{3}$ & 44.19 & 7.66 \\
\hline $\mathrm{FeO}$ & 24.68 & 4.75 \\
\hline $\mathrm{SiO}_{2}$ & 2.96 & 47.90 \\
\hline $\mathrm{Al}_{2} \mathrm{O}_{3}$ & 14.71 & 5.85 \\
\hline $\mathrm{MgO}$ & 10.31 & 23.60 \\
\hline $\mathrm{CaO}$ & 0.16 & 0.66 \\
\hline $\mathrm{TiO}_{2}$ & - & 0.16 \\
\hline $\mathrm{P}$ & 0.001 & - \\
\hline
\end{tabular}


$\mathrm{Fe} / \mathrm{Cr}$ during pre-reductive curing. Here, the carbonaceous material addition was not considered.

Pelletization material was prepared by weight partitioning several $50 \mathrm{~g}$ batches consisting of $3 \mathrm{wt} \%$ sodium silicate, with chromite the balance. To ensure intimate inter-particle contact between chromite particle, similar to that of the $\mathrm{FeCr}$ industry, each batch was milled for two minutes to ensure that $90 \%$ of the particles are below a particle size of $75 \mu \mathrm{m}^{8,12}$. Such a particle size distribution is however only required for pellets destined for pre-reduction to maximize chromite/ reductant contact points. Oxidative pellet sintering has a less conservative approach and requires that $80 \%$ of particles be below a particle size of $74 \mu \mathrm{m}$ to ensure pellet porosity ${ }^{8}$. Nevertheless, the finer of the two particle size distributions was considered in this study. In addition to particle size reduction, milling ensured the homogeneous distribution of pellet constituents. A SiC Siebtecknik laboratory disc mill was used during all milling procedures. All samples were milled for 2 min to obtain the desired particle size specification, i.e. $\mathrm{d}_{90}$ of $<75 \mu \mathrm{m}$, as proposed by Kleynhans et al. ${ }^{12}$. Nevertheless, the particle size distribution of milled materials was determined with laser diffraction particle size using a Malvern Mastersizer 2000. Samples were ultrasonicated in deionized water before measurements to avoid the use of chemical dispersants. Stirring was set to $2000 \mathrm{rpm}$ and laser obscuration was maintained between 10 to $15 \%$. The average $d_{90}$ value of milled materials was $73.1 \pm 2.1 \mu \mathrm{m}$.

Various additives, in conjuration with sodium silicate, were also evaluated. This was done by preparing several $50 \mathrm{~g}$ batches containing $3 \mathrm{wt} \%$ sodium silicate and 3 to $12 \mathrm{wt} \%$ of a respective additive, with chromite the balance, in a similar manner as the batches containing only $3 \mathrm{wt} \%$ sodium silicate.

Green pellets were generated using a LRXplus strength tester operating with a $5 \mathrm{kN}$ load cell in standard ambient temperature and pressure conditions. The relative humidity was between 40 to $50 \%$. Each green pellet consisted of $3 \mathrm{~g}$ dry material, to which $6 \mathrm{wt} \%$ moisture (based on the pellet mass) was added before the pellet generation procedures. The $6 \mathrm{wt} \%$ moisture was selected as it ensured that no moisture was displaced from pellets during the pellet generation procedure. Moisture sources included water, carbonated water, and $\mathrm{KOH}$ solutions with differing concentrations. Moist pellet material was placed in a Specac PT No. 3000 $13 \mathrm{~mm}$ die set and compressed at a rate of $15 \mathrm{~mm} / \mathrm{min}$ until a load of $1.5 \mathrm{kN}$ was achieved, and maintained for $30 \mathrm{sec}$. Green pellets were then carefully removed from the die set to ensure that the shape of the as-pressed pellet was not altered. Green pellets were therefore cylindrical, with a diameter and length of 13 and $8 \mathrm{~mm}$, respectively. This pelletization method was preferred over disk and drum pelletization as it ensured that generated pellets had consistent size, shape, and densities, allowing a mono-variance investigation of the experimental parameters considered in this study.

\subsection{Green pellet curing}

Several pellet curing procedures were investigated in this study: (i) air drying, where pellets were allowed to dry for up to 32 days (unless specified otherwise) and were not exposed to direct sunlight; (ii) sintering at elevated temperatures of $500,600,700$, and $800^{\circ} \mathrm{C}$, performed in a
Lenton Elite, UK, model BRD 15/5 chamber furnace with a programmable controller. Green pellets were loaded within the furnace hot zone at ambient temperature. The temperature was then increased at the furnace's maximum allowable rate of $17{ }^{\circ} \mathrm{C} / \mathrm{min}$ until the pre-designated temperature was reached. Thereafter, pellets were allowed to cool to room temperature while still within the furnace; (iii) low temperature curing at $75^{\circ} \mathrm{C}$ for $24 \mathrm{~h}$, performed by placing pellets in a pre-heated Heraeus drying furnace. Pellets were removed from the furnace after curing and cooled to room temperature.

\subsection{Compressive strength testing and statistical data analysis}

The compressive strength of cured pellets was determined using the LRXplus strength tester. Cured pellets were placed on their sides (opposite of the pressing orientation) and compressed until pellet breakage occurred. The applied force was localized to a small area of the pellet and the breakage pressure reported here represented the minimum pellet strength. The breakage pressure, which was indicative of the compressive strength of an individual pellet, was recorded in $\mathrm{kN}$ and expressed as such. The compressive strengths of air-dried pellets were determined after 1, 2, 4, 8,16 , and 32 days (unless specified otherwise). Sintered and low-temperature cured pellets were experimented on directly after curing. Considering the inevitability that some statistical deviations would occur during experimentation, the compressive strengths of between 10 to 30 pellets were determined for each data set. The average compressive strength and standard deviations were determined and indicated throughout after eliminating possible outliners using the Q-test with a 95\% confidence level.

\subsection{Scanning electron microscopy}

Field emission scanning electron microscopy (SEM) with an energy-dispersive X-ray spectroscopy (EDS) microanalysis system was used to perform pellet morphological and chemical characterization. A FEI Quanta 250 FEG SEM with an integrated Oxford X-map EDS microanalysis system operating at $15 \mathrm{kV}$ and a working distance of $10 \mathrm{~mm}$ was used. To characterize pellet surfaces and the interiors of broken (defined as breakage induced) pellets, samples were mounted on aluminium stubs and coated with carbon using an Emscope TB 500 carbon coater before SEM investigations.

\section{Results and Discussions}

\subsection{Sodium silicate-only bonded pellets}

As far as the authors could assess, the compressive strength of cured chromite pellets produced by industry is un-reported in the peer-reviewed public domain. Thus, the exact ideal pellet compressive strength is currently unknown from literature. To formulate a compressive strength target, the following factors were considered; (i) the desired compressive strength of sintered $\mathrm{Fe}$-ore pellets for blast furnace smelting is approximately $1.47 \mathrm{kN}^{30}$, (ii) the compressive strength of pre-reduced chromite pellets obtained from a FeCr smelter was determined to be $1.54 \pm 0.50 \mathrm{kN}$ (based on 55 repeats); 
however, it is important to note that oxidative sintered pellets are typically mechanically stronger than pre-reduced pellets ${ }^{12}$, and (iii) physically strong lumpy chromite ore/pelletized chromite affords favourable smelting conditions within the furnace, which increases the metallurgical efficiency $(\% \mathrm{Cr}$ recovery) of a smelter ${ }^{8}$. Considering these factors, it was decided to maximize the compressive strength of sodium silicate bonded pellets. Concerning practical application; pellets with a compressive strength $\geq 1.5 \mathrm{kN}$ would be suitable for smelting as the reformation of fines before smelting is unlikely.

To evaluate the stand-alone use of sodium silicate as a pellet binder, $3 \mathrm{wt} \%$ sodium silicate bonded pellets using water as the moisture source (denoted $3 \mathrm{wt} \%$ sodium silicatewater) were prepared according to Curing methods i) (air drying) and ii) (sintering). The compressive strengths of these pellets are presented in Figure 1.

Figure 1a shows that the compressive strength of $3 \mathrm{wt} \%$ sodium silicate-water pellets steadily increased from $0.34 \pm 0.03$ to $1.14 \pm 0.16 \mathrm{kN}$ during the first 8 days of air-drying. No significant change in pellet compressive strength was observed for pellet cured for $>8$ days. The compressive strength of pellets cured for 16, 32, and 64 days (not included in Figure 1) was $1.14 \pm 0.19,1.07 \pm 0.10$, and $1.10 \pm 0.11 \mathrm{kN}$, respectively. Thus, pellets were fully cured after 8 days in the ambient atmosphere and further air-drying

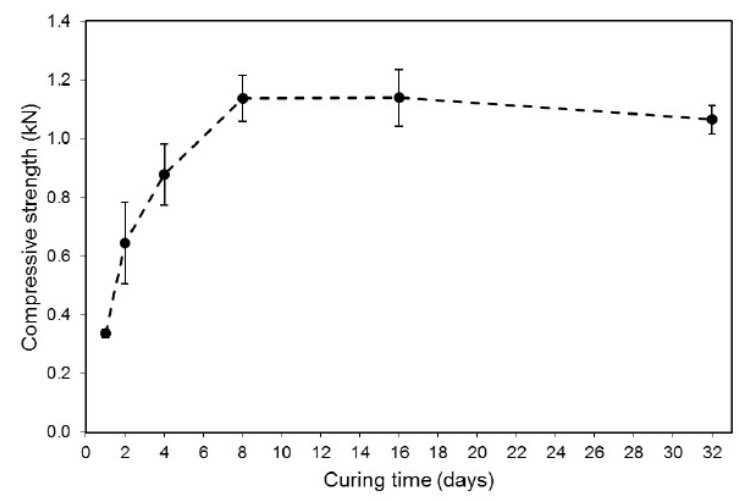

(a)

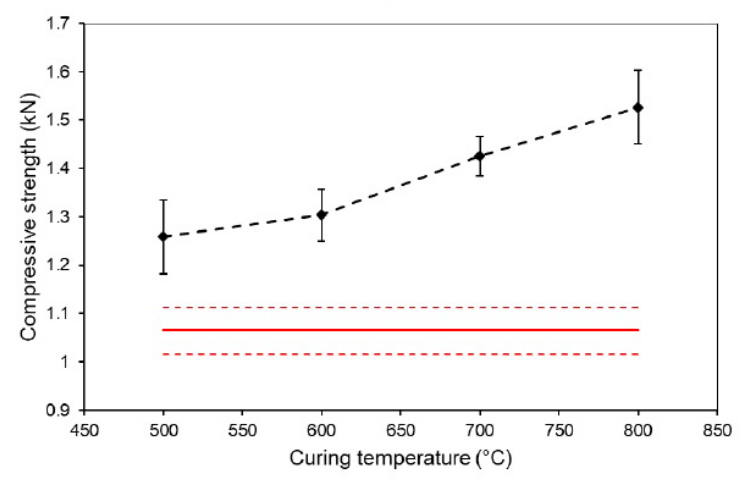

(b)

Figure 1. The compressive strength of $3 \mathrm{wt} \%$ sodium silicate-water pellets air-dried for up to 32 days (a) and sintered at $500-800{ }^{\circ} \mathrm{C}$ (b). The compressive strength of 32-day air-dried pellets presented in (a) were included in (b) as the reference; compressive strength solid red line, standard deviation - dashed red line. did not appreciably affect the compressive strength. Figure $1 \mathrm{~b}$ showed a significant increase in compressive strength when compared to air-dried pellets (included as a solid red line). The compressive strengths of the pellets sintered at 500 to $800{ }^{\circ} \mathrm{C}$ increased near-linearly from $1.26 \pm 0.16$ to $1.52 \pm 0.15 \mathrm{kN}$. Of interest is that the pellet compressive strengths reported here exceed the strengths of pellets prepared similarly and cured at higher temperatures $\left(\geq 1200^{\circ} \mathrm{C}\right)$, i.e. pre-reduced or oxidative sintered attapulgite or bentonite bonded pellets thermally cured at 1250 or $1300^{\circ} \mathrm{C}$ did not exceed $0.9 \mathrm{kN}^{12}$, $\mathrm{CaCO}_{3}$ doped pellets pre-reduced at $1300^{\circ} \mathrm{C}$ had a maximum compressive strength of approximately $0.3 \mathrm{kN}^{37}$, pre-oxidized/ pre-reduced pellets sintered at 1200 to $1500{ }^{\circ} \mathrm{C}$ did not exceed $0.8 \mathrm{kN}$; one case was reported that achieved $1.18 \mathrm{kN}^{38}$. To evaluate the morphological and chemical characteristics of the inter-particle bonds formed by sodium silicate during air-drying and sintering, broken 32 days air-dried and $800^{\circ} \mathrm{C}$ sintered pellets were investigated by SEM-EDS (Figure 2).

Figure $2 \mathrm{a}$ and $2 \mathrm{~b}$ show that chromite particles are bound together by a segregated phase present on the surface of particles. The observed phase formed as a result of sodium silicate precipitation and consisted of silica gel, silicic acid, and sodium silicate ${ }^{33}$. EDS analysis of the area indicated by the white box in Figure $2 \mathrm{~b}$ revealed $\mathrm{Si}, \mathrm{Al}$, and $\mathrm{Na}$ contents of $4.2,4.4$, and $19.4 \mathrm{wt} \%$, respectively. It was further noted that the pellet interior comprised of particles with close inter-particle proximities, which was expected considering the chosen particle size distribution as stated in Section 2.2. Nevertheless, inter-particle connections formed during airdrying were relatively weak and did not afford pellets with appreciable compressive strengths.

It is clear from Figure $2 \mathrm{c}$ that the particles of the $800^{\circ} \mathrm{C}$ sintered pellet fractured either before or concurrently as interparticle bonds were broken; suggesting that the mechanical strength of bonds exceeded that of chromite particles. It was further evident from Figure $2 \mathrm{~d}$ that precipitated composites on the surface of chromite particles were crystallized during sintering at $800{ }^{\circ} \mathrm{C}$. During thermal treatment, sodium silicate exists as $\beta-\mathrm{Na}_{2} \mathrm{Si}_{2} \mathrm{O}_{5}$ and $\mathrm{SiO}_{2}$ in the cristobalite form at $<700{ }^{\circ} \mathrm{C}$, as $\mathrm{Na}_{2} \mathrm{Si}_{8} \mathrm{O}_{19}$ between 700 and $800{ }^{\circ} \mathrm{C}$, and as an amorphous phase at $>800^{\circ} \mathrm{C}^{39}$. These compounds are likely responsible for the mechanical properties of the sintered pellets. In the $\mathrm{FeCr}$ industry, chromite grains are bound together by molten silicates originating from clay binders during curing procedures, forming mechanically strong and porous pellets ${ }^{11,34,40}$. The energy required to melt clay binders is significantly higher than the energy required to produce sodium silicate based inter-particle bonds, as is evident from the high mechanical strength of $800{ }^{\circ} \mathrm{C}$ sintered pellets (Figure 1b). Though the pellet compressive strength goal of $\geq 1.5 \mathrm{kN}$ was exceeded here, an objective of this study was to avoid high-temperature curing. Nevertheless, the potential of sodium silicate as a binding agent at sintering temperatures lower than temperatures currently applied by industry was realized here.

\subsection{Carbon dioxide/ $\mathrm{HCO}_{3}^{-}$as an additive}

It is evident from results presented in Section 3.1 that unassisted (e.g. un-sintered, additive-less) sodium silicate cannot be considered as a chromite binder under the conditions 


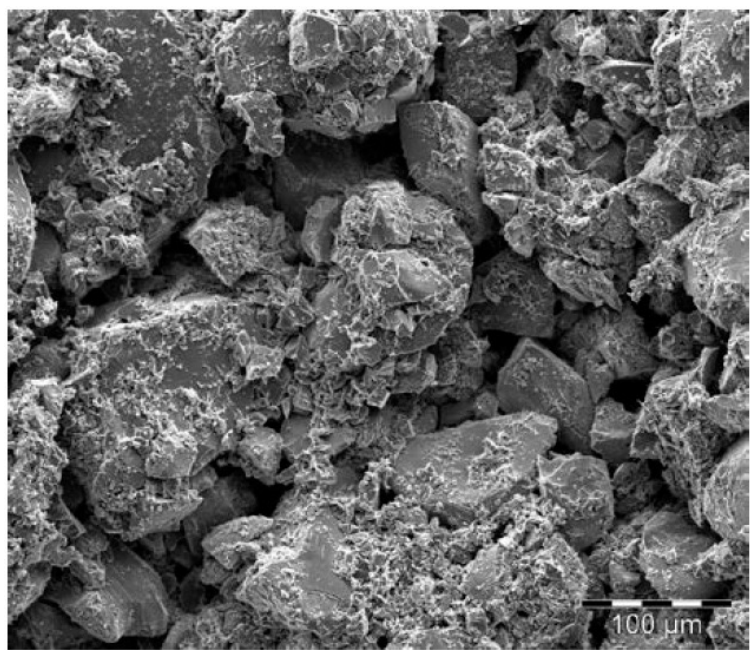

(a)

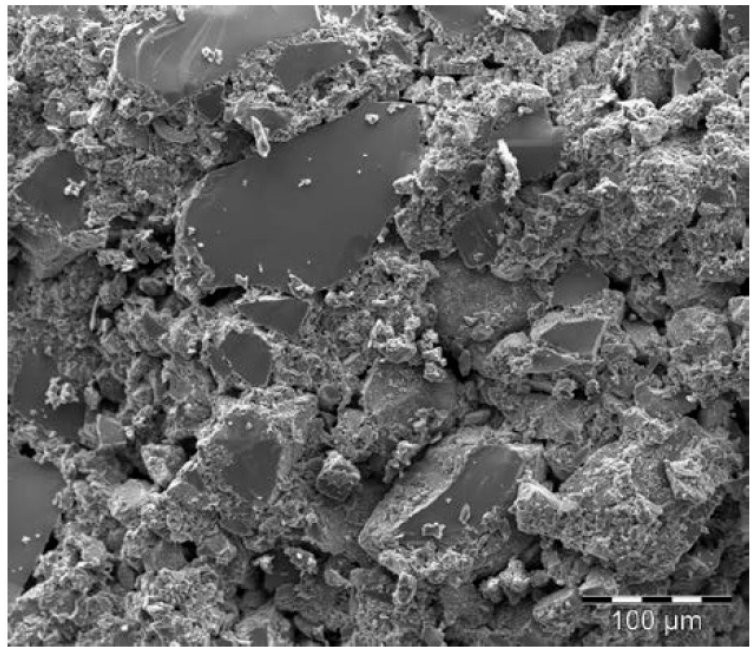

(c)

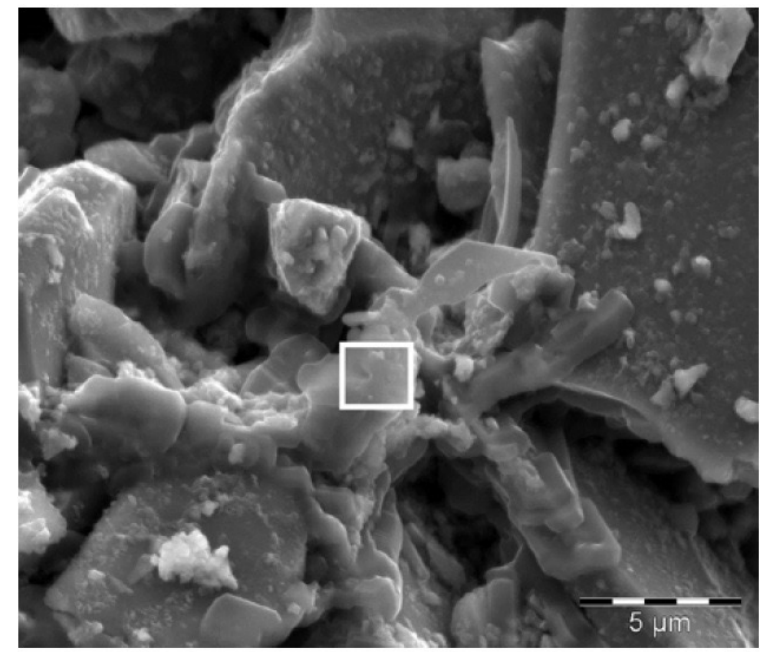

(b)

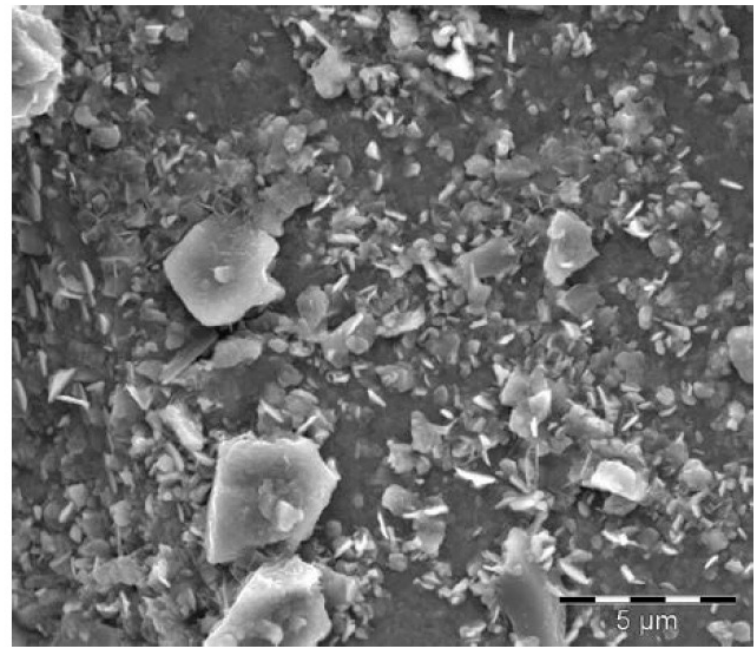

(d)

Figure 2. Backscatter SEM micrographs of the interiors of broken air-dried (a and b) and $800{ }^{\circ} \mathrm{C}$ sintered pellets (c and d).

considered in this study and that the use of an additive is necessary. In the foundry industry, $\mathrm{CO}_{2}(\mathrm{~g})$ is widely applied to accelerate sodium silicate hardening ${ }^{41-43}$. The working principle is based on the reaction between sodium silicate and $\mathrm{CO}_{2}(\mathrm{~g})$, which near-instantly hardens sodium silicate ${ }^{36}$. The use of $\mathrm{CO}_{2}(\mathrm{~g})$ my further benefit the $\mathrm{FeCr}$ industry as it may be a suitable method to utilize some $\mathrm{CO}_{2}(\mathrm{~g})$ produced during smelting procedures - reducing carbon taxes. Watersolubilized sodium silicate reacts with $\mathrm{CO}_{2}(\mathrm{~g})$ according to the following equation ${ }^{36,42,44}$ :

$$
\mathrm{Na}_{2} \mathrm{O} \cdot \mathrm{mSiO}_{2} \cdot x \mathrm{H}_{2} \mathrm{O}+\mathrm{CO}_{2} \rightarrow \mathrm{Na}_{2} \mathrm{CO}_{3}+\mathrm{mSiO}_{2} \cdot x \mathrm{H}_{2} \mathrm{O}
$$

Jain (2003) stated that the mechanical strength of sodium silicate bonded refractory moulds may be ascribed to the formation of $m \mathrm{SiO}_{2} \cdot x \mathrm{H}_{2} \mathrm{O}$ (silica gel) on the surface of refractory sand grains, forming inter-particle bonds ${ }^{36}$. Based on Equation 1, gaseous and dissolved $\mathrm{CO}_{2}$ sources were considered to promote sodium silicate bonded pellet hardening; as well as a $\mathrm{HCO}_{3}{ }^{-}$based additive, $\mathrm{NaHCO}_{3}$. Pellets were prepared as follow: (i) $3 \mathrm{wt} \%$ sodium silicate-water pellets were prepared and cured for 32 days in a saturated $\mathrm{CO}_{2}$ (g) environment, (ii) $3 \mathrm{wt} \%$ sodium silicate- $3 \mathrm{wt} \%$ $\mathrm{NaHCO}_{3}$-water pellets and (iii) $3 \mathrm{wt} \%$ sodium silicatecarbonated water pellets were prepared and air-dried for 32 days. Pellet compressive strengths were determined and presented in Figure 3.

It is evident from Figure 3 that the initial compressive strengths of $3 \mathrm{wt} \%$ sodium silicate- $3 \mathrm{wt} \% \mathrm{NaHCO}_{3}$-water and $3 \mathrm{wt} \%$ sodium silicate-carbonated water pellets were similar to or exceeded the reference. However, in both cases, the compressive strengths readily decreased after 4 to 8 days of air-drying. The observed compressive strength decreases were likely caused by the presence of $\mathrm{Al}_{2} \mathrm{O}_{3}$ originating from the chromite spinel. VenkataRamana (2014) stated that $\mathrm{Al}_{2} \mathrm{O}_{3}$ is typically added to $\mathrm{CO}_{2}$ cured sodium silicate 
bonded refractory moulds, which delays the formation of $\mathrm{Na}_{2} \mathrm{CO}_{3}$ and $m \mathrm{SiO}_{2} \cdot x \mathrm{H}_{2} \mathrm{O}$ and consequently increases its collapsibility $^{42}$. The pellets cured in a $\mathrm{CO}_{2}$ environment did not exceed a compressive strength of $\leq 0.16 \mathrm{kN}$ after 32 days of curing. As soon as these pellets were placed in the $\mathrm{CO}_{2}(\mathrm{~g})$ atmosphere, a white crystalline layer formed on the pellet surface. This was indicative of the reaction between sodium silicate and $\mathrm{CO}_{2}$, as indicated in Equation 1. To investigate this, SEM micrographs of the surface and interior of these pellets were prepared and are presented in Figure 4.

It is evident from Figure $4 \mathrm{a}$ that crystallization occurred on the pellet surface, whereas no such crystallization was observed within the pellet interior (Figure 4b). The observed crystal layer may be ascribed to a phenomenon referred to as over-gassing, which is defined as reacting sodium silicate with an excessive amount of $\mathrm{CO}_{2}$. According to Jain (2003), a sodium silicate: $\mathrm{CO}_{2}$ mass ratio of 1:0.5 to 0.75 is estimated as satisfactory ${ }^{36}$. VenkataRamana (2014) further stated that silicate bonds are weakened as a result of dehydration if an excessive amount of $\mathrm{CO}_{2}$ is used during curing ${ }^{42}$. Considering the saturated $\mathrm{CO}_{2}$ atmosphere used to cure the pellets presented in Figure 4, it is likely that dehydration of the surface silicate bonds occurred. Another likely contributing factor that limited $\mathrm{CO}_{2}$ assisted sodium silicate hardening is the high particle density observed in Figure $4 \mathrm{~b}$ and coinciding lack of porosity - preventing $\mathrm{CO}_{2}$ from penetrating beyond the pellet surface. The use of coarser chromite should be considered as a future prospective; coarser chromite requires less energy input during milling, reducing the associated costs. Nevertheless, it may be concluded that

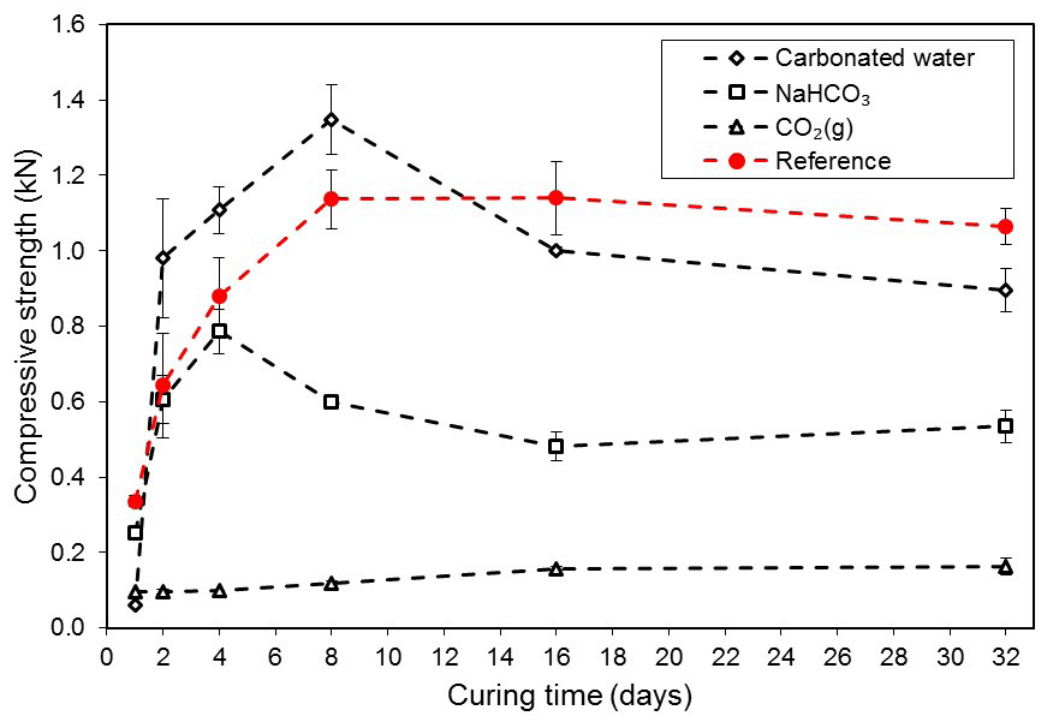

Figure 3. The average compressive strength of $3 \mathrm{wt} \%$ sodium silicate pellets prepared using various $\mathrm{CO}_{2}$ sources and cured for up to 32 days.

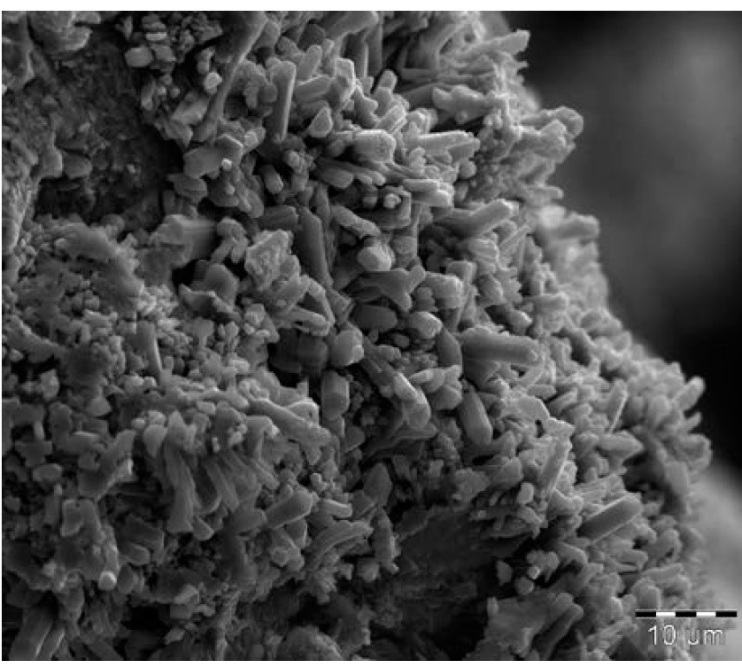

(a)

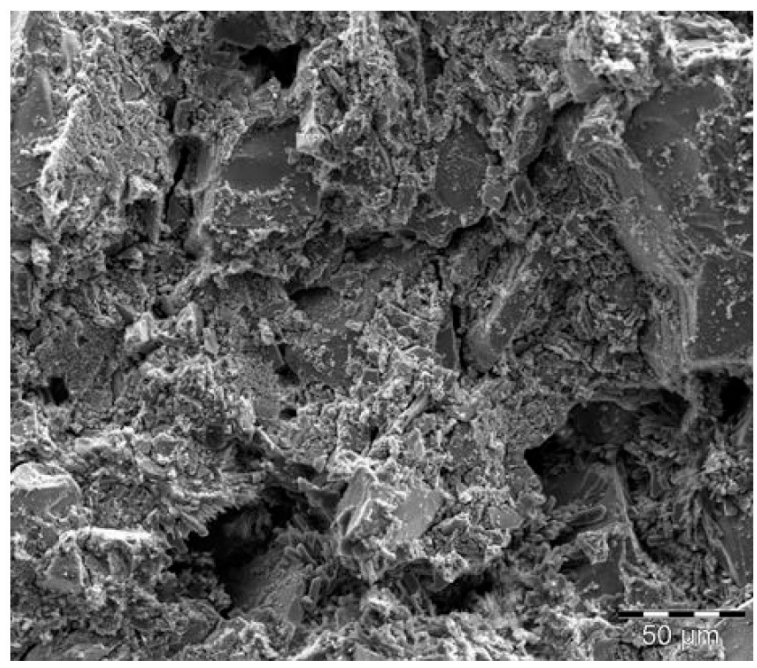

(b)

Figure 4. Backscatter SEM micrographs of the surface (a) and interior (b) of a $3 \mathrm{wt} \%$ sodium silicate bonded pellet dried for 32 days in a $\mathrm{CO}_{2}(\mathrm{~g})$ atmosphere. 
the additives considered in this section may not be applied to prepare mechanically strong pellets.

\subsection{Additives to promote geopolymerization}

The limited success achieved in the preceding sections suggests an alternative approach to prepare sodium silicate bonded chromite pellets. Thus, the use of geopolymers (mineral polymers) was considered as geopolymer-bonded structures may possess excellent mechanical properties ${ }^{45-47}$. According to $\mathrm{Xu}$ and Van Deventer ${ }^{47}$ and Autef et al. ${ }^{48}$, geopolymers form as a result of the co-precipitation of silicate- and alumino species, which originates from the dissolution of source material $\mathrm{Si}$ and $\mathrm{Al}$ at elevated $\mathrm{pH}$ levels and in the presence of soluble alkali metal silicates. Dissolved $\mathrm{Si}$ and $\mathrm{Al}$ co-polymerize to form the (Si-O-Al-O) bonds required for geopolymer formation. This reaction mechanism can be schematized as shown in Figure $5^{47,49}$.

The reaction steps presented in Figure 5 suggest that under certain conditions, any $\mathrm{SiO}_{2}$ and $\mathrm{Al}_{2} \mathrm{O}_{3}$ containing mineral can be used as source material for geopolymerization ${ }^{50}$. However, geopolymerization typically utilize source materials with high $\mathrm{SiO}_{2}$ and $\mathrm{Al}_{2} \mathrm{O}_{3}$ contents, e.g. furnace slag, fly ash, kaolinite, metakaolinite, pozzolan, albite, and blast-furnace slag, with $\mathrm{SiO}_{2}$ contents of between 32 to $71 \mathrm{wt} \%$ and $\mathrm{Al}_{2} \mathrm{O}_{3}$ contents of between 14 to $33 \mathrm{wt} \%{ }^{47,51-54}$. In this study, a South African chromite ore was used as the source material and had $\mathrm{SiO}_{2}$ and $\mathrm{Al}_{2} \mathrm{O}_{3}$ contents of 2.96 and $14.71 \mathrm{wt} \%$, respectively. The chemical composition of chromite from the various chromite mining countries differs, as summarized in Table 2.

Table 2 suggests that the average $\mathrm{SiO}_{2}$ content of chromite is far below that of typical source materials used for geopolymerization, whereas the average $\mathrm{Al}_{2} \mathrm{O}_{3}$ content of chromite ranges between below or slightly above the lower $\mathrm{Al}_{2} \mathrm{O}_{3}$ content of typical source materials. Thus, assuming complete $\mathrm{Si}$ and $\mathrm{Al}$ dissolution, the possibility exists that the $\mathrm{Si}$ and $\mathrm{Al}$ contents of chromite could still be insufficient for geopolymerization. To promote chromite's geopolymerization, non-source material $\mathrm{SiO}_{2}$ and $\mathrm{Al}_{2} \mathrm{O}_{3}$ were introduced to pellets. In addition to this, it was considered that the sodium silicate content may not be able to generate an environment with sufficient alkalinity to facilitate source material and non-source material $\mathrm{SiO}_{2}$ and $\mathrm{Al}_{2} \mathrm{O}_{3}$ dissolution. This occurrence may be mitigated by the addition of an alkaline activator, which in conjuration with sodium silicate, could promote the latter mentioned $\mathrm{SiO}_{2}$ and $\mathrm{Al}_{2} \mathrm{O}_{3}$ dissolutions. For instance, the cement industry utilizes $\mathrm{SiO}_{2}$ - and $\mathrm{Al}_{2} \mathrm{O}_{3}$-rich source materials in conjuration with an alkaline hydroxide activator to prepare high compressive strength solid matrices, with increasingly stronger matrices obtainable with increasingly higher alkaline contents ${ }^{54,58}$. Therefore, the effects of water and a $2 \mathrm{M} \mathrm{KOH}$ solution as moisture sources were evaluated. The following pellets were prepared: (i) $3 \mathrm{wt} \%$ sodium silicate- $3 \mathrm{wt} \% \mathrm{SiO}_{2}$ and $/$ or $\mathrm{Al}_{2} \mathrm{O}_{3}$-water, and (ii) $3 \mathrm{wt} \%$ sodium silicate- $3 \mathrm{wt} \% \mathrm{SiO}_{2}$ and/or $\mathrm{Al}_{2} \mathrm{O}_{3}-2 \mathrm{M} \mathrm{KOH}$.

It is clear from Figure 6 that none of the prepared pellets had appreciable compressive strengths after air-drying. The low compressive strengths presented in Figure 6a may be ascribed to sodium silicate's inability to generate an environment with sufficient alkalinity to enable $\mathrm{Al}$ and $\mathrm{Si}$ to be solubilized and partake in the geopolymerization process. However, when considering the low compressive strengths presented in Figure 6b; the addition of $\mathrm{KOH}$ as an alkaline activator did not show significant compressive strength increases when compared to the reference and the majority of pellets prepared with water. Here, only the $3 \mathrm{wt} \%$ sodium silicate-3 $\mathrm{wt} \% \mathrm{SiO}_{2}-2 \mathrm{M} \mathrm{KOH}$ had an improved compressive strength after 21 days of curing; the compressive strength was still below the reference.
$n\left(\mathrm{Si}_{2} \mathrm{O}_{5}, \mathrm{Al}_{2} \mathrm{O}_{2}\right)+2 n \mathrm{SiO}_{2}+4 n \mathrm{H}_{2} \mathrm{O}+\mathrm{NaOH} / \mathrm{KOH} \rightarrow \mathrm{Na}^{+}, \mathrm{K}^{+}+n(\mathrm{OH})_{3}-\mathrm{Si}-\mathrm{O}-\mathrm{Al}_{1}^{-}-\mathrm{O}-\mathrm{Si}-(\mathrm{OH})_{3}$ (Si-Al materials)
$(\mathrm{OH})_{2}$

(Geopolymer backbone)

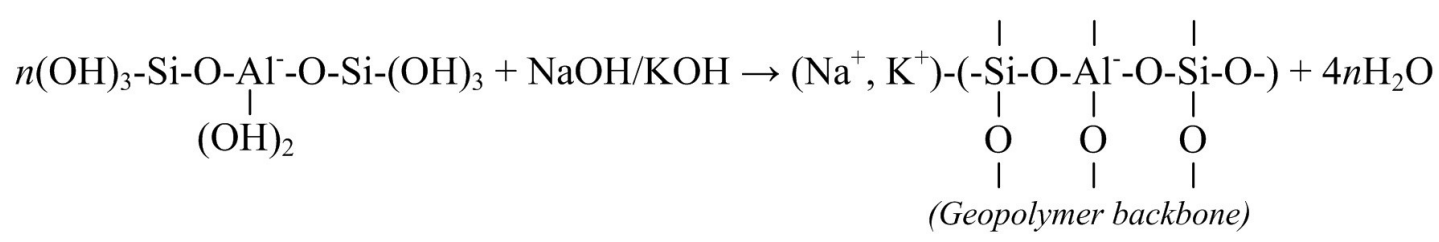

Figure 5. Schematic diagram of reaction steps involved during geopolymer formation.

Table 2. Average $\mathrm{SiO}_{2}$ and $\mathrm{Al}_{2} \mathrm{O}_{3}$ content of chromite from various countries.

\begin{tabular}{cccc}
\hline Country & $\mathrm{SiO}_{2}(\mathrm{wt} \%)$ & $\mathrm{Al}_{2} \mathrm{O}_{3}(\mathrm{wt} \%)$ & Reference \\
\hline South Africa & & $15.7 \pm 0.8$ & Glastonbury et al. $^{16}$ \\
\hline Brazil $^{16}$ & $3.2 \pm 0.2$ & 17.3 & Zambrano et al. $^{33}$ \\
\hline Kazakhstan $^{2}$ & 5.7 & $6.7 \pm 0.6$ & McCullough et al. $^{55}$ \\
\hline Canada $^{3}$ & $6.3 \pm 1.1$ & $11.2 \pm 0.3$ & Yu and Paktunc $^{56}$ \\
\hline Zimbabwe $^{4}$ & $3.6 \pm 0.7$ & $11.7 \pm 0.8$ & Zhou and Kerrich $^{57}$ \\
\hline
\end{tabular}

'based as the average of two different chromite grades, i.e. metallurgical (used here) and UG2 (chromite-rich residue of South African platinum industry); ${ }^{2}$ based on four values; ${ }^{3}$ based on chromite of 75 to $300 \mu \mathrm{m}$ size fraction; ${ }^{4}$ based on 14 values 
It was further evident that the compressive strengths of $\mathrm{Al}_{2} \mathrm{O}_{3}$ and $\mathrm{Al}_{2} \mathrm{O}_{3}-\mathrm{SiO}_{2}$ containing pellets prepared using water or $2 \mathrm{M} \mathrm{KOH}$ were weaker than pellets containing only $\mathrm{SiO}_{2}$. Silva et al. ${ }^{59}$ stated that a geopolymer system with an elevated Al content afforded the formation of large segregated $\mathrm{Na}$ Al-Si grains, as appose geopolymers containing amorphous $\mathrm{Na}-\mathrm{Al}-\mathrm{Si}$ for low Al-containing systems. In addition to this, in the presence of Al, excess alkali affords the formation of carbonates when exposed to the atmosphere, which may have adverse effects on the structural properties ${ }^{60,61}$. Pellets containing only $\mathrm{SiO}_{2}$ initially showed compressive strength increases; however, a decreased from $1.1 \pm 0.3$ to $0.8 \pm 0.2 \mathrm{kN}$ was observed after 21 and 32 days of air-drying, respectively. The observed decreases may likely be ascribed to an increase in local humidity, as this study was performed during the South African rainy season, highlighting the hygroscopic nature of sodium silicate. This was a critical observation and will be further contextualized in the following text.
Regardless of the insufficient compressive strength of the pellets presented in Figures $6 a$ and $b$; the use of BFD as an $\mathrm{Al}$ and $\mathrm{Si}$ source material was explored as it has an $\mathrm{Al}_{2} \mathrm{O}_{3}$ content of $5.85 \mathrm{wt} \%$ and $\mathrm{SiO}_{2}$ content of $47.90 \mathrm{wt} \%$ (Table 1). BFD is readily available at any $\mathrm{FeCr}$ produce utilizing semi-closed SAFs as it originates from bag houses used to remove particulate matter from furnace off-gas before being released into the environment. BFD contains a significant amount of $\mathrm{Cr}(\mathrm{VI})^{5,23,26}$. As appose to the storage of BFD, disposal thereof as a pellet constituent would be greatly beneficial to the $\mathrm{FeCr}$ industry. $\mathrm{Cr}$ (VI) reintroduced to the smelting process would be reduced to either $\mathrm{Cr}$ (III) or metallic $\mathrm{Cr}$; thus dismissing concerns relating to $\mathrm{Cr}$ (VI). Pellets containing $3 \mathrm{wt} \%$ sodium silicate- $3 \mathrm{wt} \%$ BFD-water or $2 \mathrm{M} \mathrm{KOH}$ were prepared and their compressive strengths determined (Figure 7).

Figure 7 shows that BFD containing pellets prepared using water or $2 \mathrm{M} \mathrm{KOH}$ as the moisture sources did not

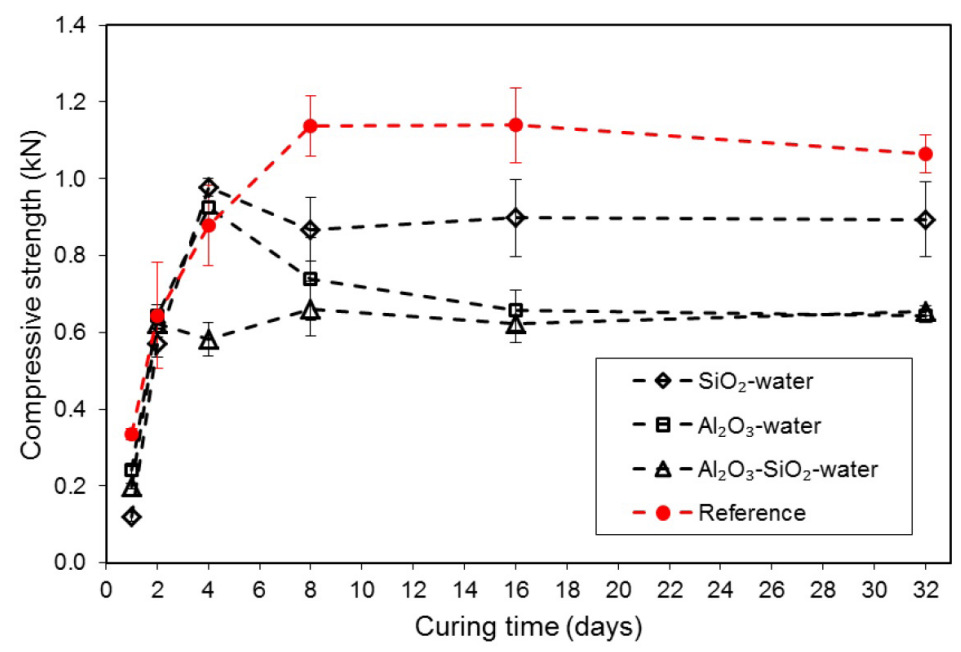

(a)

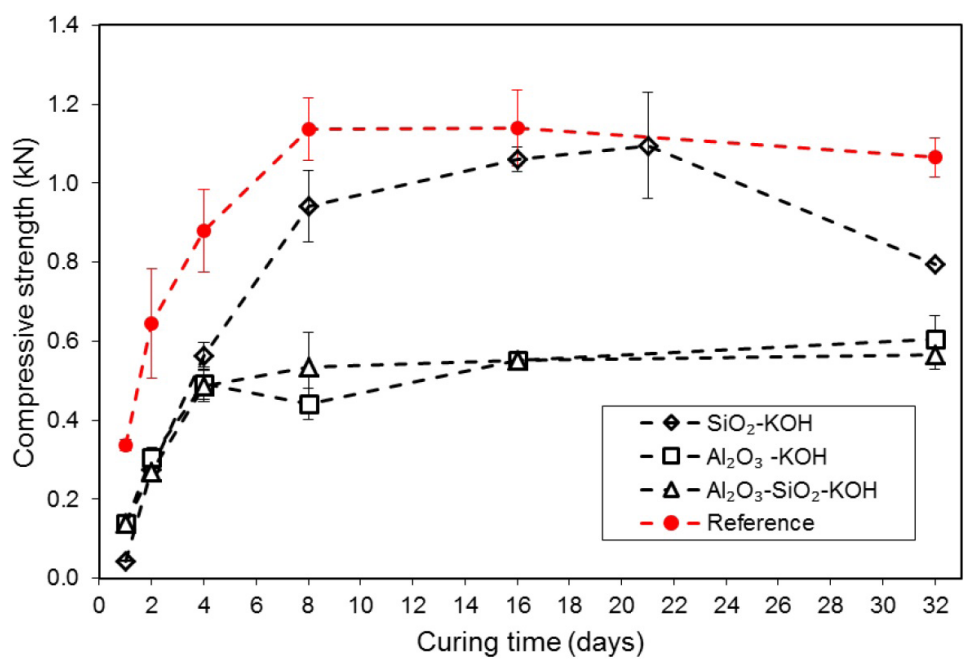

(b)

Figure 6. The average compression strengths of $3 \mathrm{wt} \%$ sodium silicate- $3 \mathrm{wt} \% \mathrm{SiO}_{2}$ and $/ \mathrm{or}^{\mathrm{Al}} \mathrm{O}_{2}$-water pellets (a) and $3 \mathrm{wt} \% \mathrm{sodium}$ silicate-3 $\mathrm{wt} \% \mathrm{SiO}_{2}$ and $/$ or $\mathrm{Al}_{2} \mathrm{O}_{3}-2 \mathrm{M} \mathrm{KOH}$ pellets (b) air-dried for up to 32 days. 


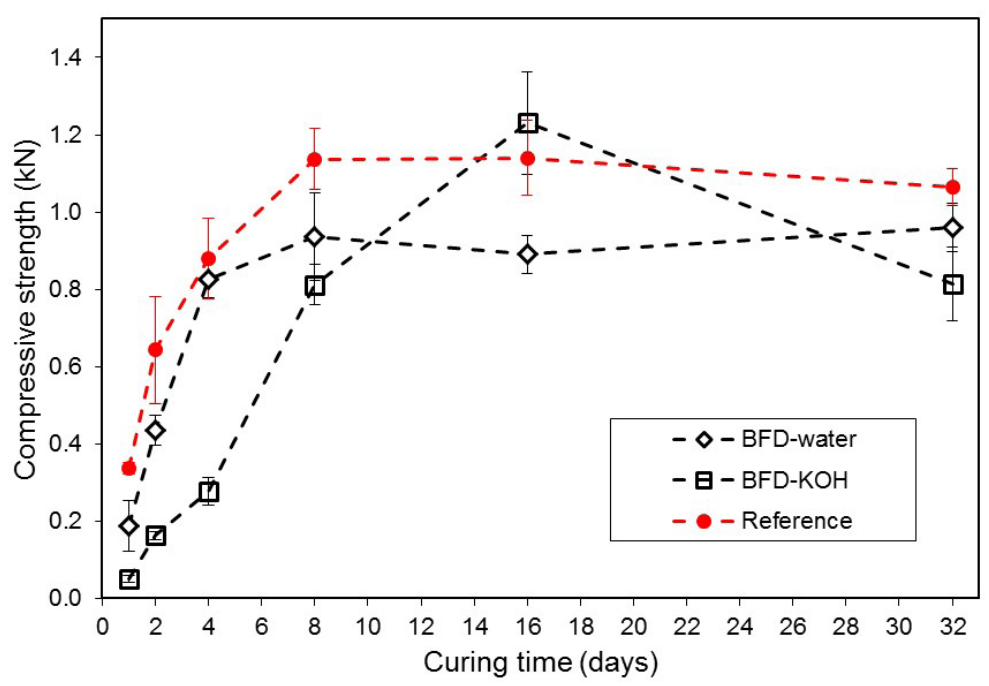

Figure 7. The average compressive strength of $3 \mathrm{wt} \%$ sodium silicate- $3 \mathrm{wt} \%$ BFD-water or $2 \mathrm{M} \mathrm{KOH}$ pellets air-dried for up to 32 days.

yield mechanically strong pellets. Only one instance was observed where the compressive strength exceeded that of the reference, i.e. $3 \mathrm{wt} \%$ sodium silicate- $3 \mathrm{wt} \%$ BFD-2 $\mathrm{M} \mathrm{KOH}$ solution after 16 days of air-drying. However, the compressive strength readily decreased from $1.23 \pm 0.25$ to $0.81 \pm 0.19 \mathrm{KN}$ after 32 days of air-drying. This decrease may be ascribed to local rainfall, reiterating the susceptibility of sodium silicate bonded pellets to moisture. Nevertheless, it was clear that BFD containing pellets were not suitable for smelting procedures.

The following conclusions may be made from this section: i) $\mathrm{SiO}_{2}$ showed potential as an additive to promote pellet strength, ii) non-source material $\mathrm{Al}_{2} \mathrm{O}_{3}$ additions, in conjuration with $\mathrm{KOH}$, adversely affected pellet strength, and iii) sodium silicate bonded and air-dried pellets showed significant moisture susceptibility. Thus, pellets prepared here were not suitable for the $\mathrm{FeCr}$ industry.

\subsection{Effects of low-temperature curing, $\mathrm{SiO}_{2}$ and $\mathrm{KOH}$ content}

It was evident from the preceding sections that the compressive strengths of air-dried pellets cured at ambient temperature were unsatisfactory - regardless of the additives considered. A study by Kirschner and Harmuth (2004) found that curing a geopolymer-bonded meta-kaoline structure at $75^{\circ} \mathrm{C}$ for $4 \mathrm{~h}$ yielded satisfactory mechanical properties, whereas 28 days of curing at ambient temperature did not ${ }^{62}$. Geopolymer curing at higher than ambient temperatures $\left(<100^{\circ} \mathrm{C}\right)$ increases source material dissolution which promotes binder efficiency ${ }^{62,63}$. In the FeCr industry, allocating waste heat to pellet curing is not a difficult undertaking. For instance, CO-rich closed furnace off-gas combusts at temperatures between 1790 to $2250{ }^{\circ} \mathrm{C}$, depending on its composition $^{23,64}$; by diverting and combusting some of this off-gas to a fit-for-purpose pellet curing plant may easily generate sufficient heat to afford geopolymer bonded pellet curing. Thus, to evaluate the effects of higher than ambient curing temperature, pellets were cured at $75^{\circ} \mathrm{C}$ for $24 \mathrm{~h}$ (i.e.
Curing method (iii), Section 2.3). Furthermore, it is evident from the preceding sections that the compressive strength of $\mathrm{SiO}_{2}$ containing pellets showed the most potential if compared to $\mathrm{Al}_{2} \mathrm{O}_{3}$ containing pellets. The geopolymerization process is strongly affected by the $\mathrm{SiO}_{2} / \mathrm{Al}_{2} \mathrm{O}_{3}$ ratio and the addition of $\mathrm{Al}_{2} \mathrm{O}_{3}$ yielded a non-favourable $\mathrm{SiO}_{2} / \mathrm{Al}_{2} \mathrm{O}_{3}$ ratio. Silva et al. ${ }^{59}$ stated that $\mathrm{SiO} / \mathrm{Al}_{2} \mathrm{O}_{3}$ molar ratios of 3.4 to 3.8 afforded metakaolin geopolymer bonded structures with optimal strengths. To determine a suitable $\mathrm{SiO}_{2} / \mathrm{Al}_{2} \mathrm{O}_{3}$ ratio, pellets containing various $\mathrm{SiO}_{2}$ additions were prepared with a $2 \mathrm{M} \mathrm{KOH}$ solution as the moisture source and cured at low temperature. In addition to this, the effect of $\mathrm{KOH}$ concentration was also determined. These results are presented in Figure 8.

Figure $8 \mathrm{a}$ shows that the pellet compressive strength increased from $1.89 \pm 0.34$ to $2.46 \pm 0.15 \mathrm{kN}$ as the $\mathrm{SiO}_{2}$ content was increased from 1.5 to $3.0 \mathrm{wt} \%$. By further increasing the $\mathrm{SiO}_{2}$ content to $12.0 \mathrm{wt} \%$ systematically decreased the compressive strength to $0.11 \pm 0.01 \mathrm{kN}$ - suggesting that a $\mathrm{SiO}_{2} / \mathrm{Al}_{2} \mathrm{O}_{3}$ ratio of 1.99 yielded pellets with optimal compressive strength at a curing temperature of $75^{\circ} \mathrm{C}$. The correlation between $\mathrm{SiO}_{2} / \mathrm{Al}_{2} \mathrm{O}_{3}$ and compressive strength were comparable to the results presented by Silva et al. ${ }^{59}$ and Duxson et al. ${ }^{65}$. Considering this, mechanically strong pellets may likely be prepared from any chromite sources (presented in Table 2) by altering the $\mathrm{SiO}_{2} / \mathrm{Al}_{2} \mathrm{O}_{3}$ ratio to 1.99 by the addition of non-source material $\mathrm{SiO}_{2}$ or $\mathrm{Al}_{2} \mathrm{O}_{3}$. It is however noted that the effects of curing temperature, as a function of $\mathrm{SiO}_{2}: \mathrm{Al}_{2} \mathrm{O}_{3}$ ratio, should be explored in future.

It was evident from Figure $8 \mathrm{~b}$ that all investigated $\mathrm{KOH}$ concentrations investigated produced pellets with significantly higher compressive strengths than the reference. Pellets prepared using 1 and $2 \mathrm{M} \mathrm{KOH}$ solutions had compressive strengths of $2.56 \pm 0.44$ and $2.46 \pm 0.15 \mathrm{kN}$, whereas the pellets prepared using 4 and $6 \mathrm{M} \mathrm{KOH}$ solutions had strengths of $3.12 \pm 0.16$ and $2.41 \pm 0.30 \mathrm{kN}$. Of interest here was that the compressive strength peaked at $4 \mathrm{M} \mathrm{KOH}$. Is was expected that with an increase in alkaline content, more 
$\mathrm{SiO}_{2}$ and $\mathrm{Al}_{2} \mathrm{O}_{3}$ would be dissolved and to partake in the geopolymerization process ${ }^{48}$ - which was not the case here. Nair et al. ${ }^{66}$ found that a 1:1 molar ratio of $\mathrm{KOH} /$ anorthite $\left(\mathrm{CaO} \cdot \mathrm{Al}_{2} \mathrm{O}_{3} \cdot 2 \mathrm{SiO}_{2}\right)$ yielded a geopolymer bonded material

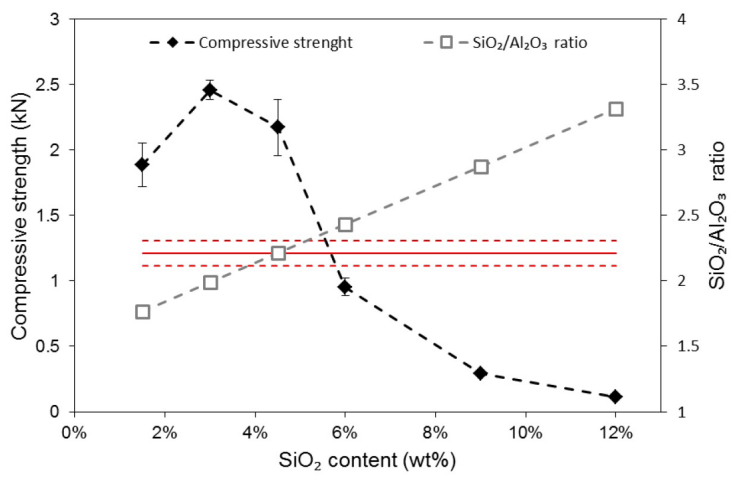

(a)

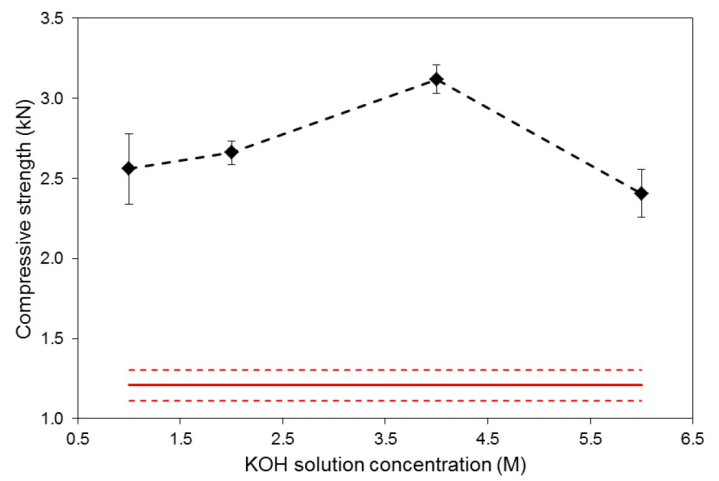

(b)

Figure 8. The average compressive strength and $\mathrm{SiO}_{2} / \mathrm{Al}_{2} \mathrm{O}_{3}$ ratios of $3 \mathrm{wt} \%$ sodium silicate- 1.5 to $12 \mathrm{wt} \% \mathrm{SiO}_{2}-2 \mathrm{M} \mathrm{KOH}$ pellets cured at $75^{\circ} \mathrm{C}$ for $24 \mathrm{~h}$ (a) and $3 \mathrm{wt} \%$ sodium silicate- $3 \mathrm{wt} \% \mathrm{SiO}_{2}-1,2,4$, $6 \mathrm{M} \mathrm{KOH}$ pellets cured at $75^{\circ} \mathrm{C}$ for $24 \mathrm{~h}(\mathrm{~b})$. with exceptional compressive strength. For anorthite based geopolymerization, the ideal $\mathrm{KOH}$ /anorthite ratio affords aluminsilicate particles to be embedded as uniformly distributed secondary phase particles in the geopolymer gel phase during solidification. The same principle likely applied here; however, the $\mathrm{KOH} /$ chromite ratio will differ from for each chromite source due to a significant difference in the chemical composition of chromite from the various source countries. Nevertheless, the optimal $\mathrm{KOH}$ concentration of $4 \mathrm{M}$ $\mathrm{KOH}$ was identified to produce mechanically strong chromite pellets. When considering industrial practices, elevated $\mathrm{pH}$ solutions are generally avoided. Thus, it would be logical for industry to prepare pellets with sufficient mechanical strength using low alkalinity solutions, i.e. $1 \mathrm{M} \mathrm{KOH}$. It is also suggested that $<1 \mathrm{M} \mathrm{KOH}$ solutions be investigated in future. The binding mechanism of a broken $3 \mathrm{wt} \%$ sodium silicate- $3 \mathrm{wt} \% \mathrm{SiO}_{2}-2 \mathrm{M} \mathrm{KOH}$ pellet was investigated by SEM (Figure 9).

Two prominent features are evident from Figure 9a; (i) chromite particles fractured before or concurrently with interparticle bonds - as was observed for an $800^{\circ} \mathrm{C}$ sintered pellet (Figure 2), and (ii) that numerous solid distinguishable interparticle bonds formed between the closely packed chromite particles. EDS analysis of the area indicated by the white box in Figure $9 \mathrm{~b}$ revealed $\mathrm{Si}, \mathrm{Al}$, and $\mathrm{Na} \mathrm{wt} \%$ contents of 6.7 , 5.4, and $13.9 \mathrm{wt} \%$, respectively. The $\mathrm{Si}$ and $\mathrm{Al}$ contents were higher than for the bond presented in Figure 2a, whereas the $\mathrm{Na}$ content was lower. It should be noted that $\mathrm{Na}$ detection by EDS may be under-reported due to its mobility when exposed to an electron beam ${ }^{67,68}$. Nevertheless, the improved mechanical strength of inter-particle bonds may be ascribed to the dissolution and geopolymerization of $\mathrm{SiO}_{2}$ and $\mathrm{Al}_{2} \mathrm{O}_{3}$ when present at an optimal $\mathrm{SiO}_{2} / \mathrm{Al}_{2} \mathrm{O}_{3}$ ratio of 1.99 , and rapid strength development of geopolymers induced by low-temperature curing.

Considering the high Si-content of the proposed pellet binder system, it is important to note that the effect of

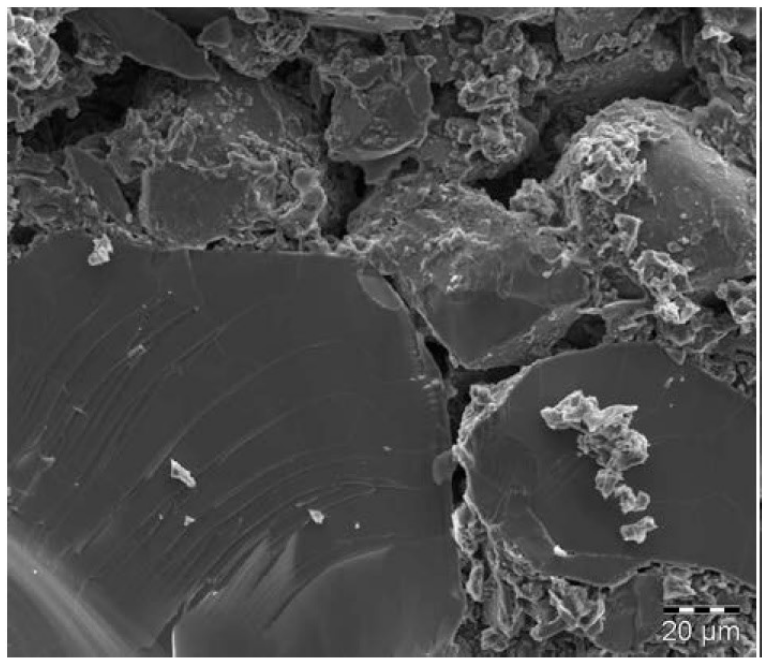

(a)

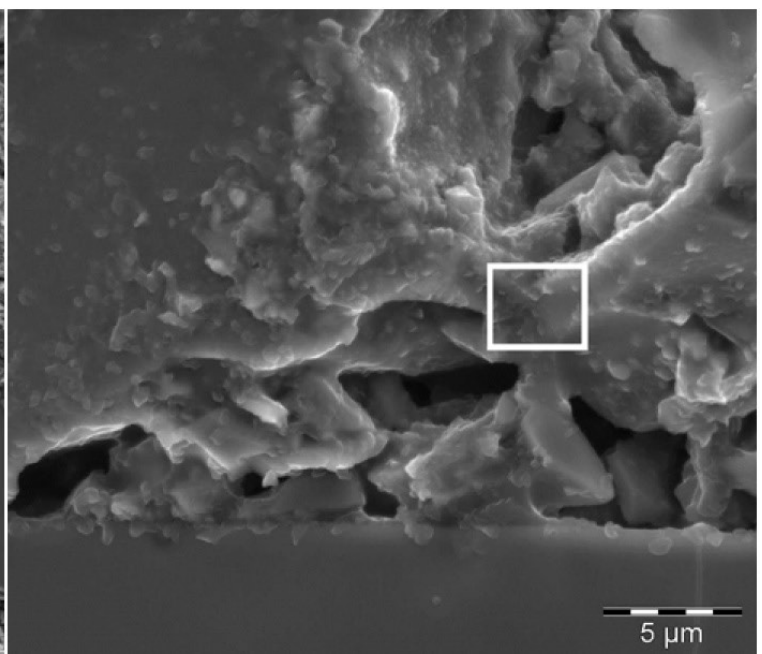

(b)

Figure 9. Backscatter SEM micrographs of the interior (a) and an inter-particle bond (b) of a broken $3 \mathrm{wt} \%$ sodium silicate- $3 \mathrm{wt} \% \mathrm{SiO}-2$ $\mathrm{M} \mathrm{KOH}$ pellet cured at $75^{\circ} \mathrm{C}$ for $24 \mathrm{~h}$. 
sodium silicate and $\mathrm{SiO}_{2}$ addition on the $\mathrm{Si}$-content of $\mathrm{FeCr}$ produced from $3 \%$ sodium silicate- $3 \% \mathrm{SiO}_{2}$ bonded chromite is currently unknown. The increase in Si-containing elements present in the pellet matrix may cause an increase in the $\mathrm{Si}$ content of $\mathrm{FeCr}$. If this is the case, it is possible that this increase may be counteracted by, for instance, decreasing the amount of flux addition during material batching, i.e., weight proportioning of lumpy/pelletized chromite, flux, and reductant before being fed to a furnace. However, material batching will be determined by the specific furnace slag regime. The basicity factor $(\mathrm{BF})$ of a furnace is determined by the following equation ${ }^{4,14,24}$ :

$$
\mathrm{BF}=\frac{\% \mathrm{CaO}+\% \mathrm{MgO}}{\% \mathrm{SiO}_{2}}
$$

Basic and acidic slag regimes have BFs of $>1$ and $<1$, respectively. SAFs and DC furnaces operate on different BFs, depending on the slag conductivity. For instance, less carbonaceous reductant is required for SAFs operating on pre-reduced chromite, which reduces the slag conductivity. Therefore, such smelting procedures operate using conductive basic slag regimes with $\mathrm{BF}$ of $>1$. In summary, the addition of $\mathrm{SiO}_{2}$ as a pellet binder should be included during $\mathrm{BF}$ calculations.

\subsection{Cured pellet moisture susceptibility}

Several decreases in pellet mechanical strengths observed in this study occurred after local rainfall. Sodium silicate bonded refractory moulds and pellets are known to deteriorate when exposed to moisture/humid environments ${ }^{33,69}$. In the ferrochrome industry, the majority of oxidative sintered pellets and approximately $5 \%$ of pre-reduced pellets are stored in open, unroofed environments for extended periods before smelting procedures ${ }^{14}$. More so, in most cases pelletization plants continue to operate during furnace shut-downs, causing a build-up of pellets. Thus, it is almost a certainty that significant quantities of pellets will be exposed to rain. The effect of moisture on the compressive strength of two sets of pellets produced in this study, i.e. $3 \mathrm{wt} \%$ sodium silicate- $3 \mathrm{wt} \% \mathrm{SiO}_{2}-1 \mathrm{M}$ and $4 \mathrm{M} \mathrm{KOH}$ were selected for this investigation. A container was filled with water, and cured pellets were placed on a grid approximate $10 \mathrm{~mm}$ above the water level. The container was sealed and placed in direct sunlight. Pellets were retrieved after 10 days, and their compressive strengths determined. The moisture exposed pellets did not indicate any decrease in compressive strength, suggesting that such pellets may be produced by $\mathrm{FeCr}$ producers and stored without taking any special precautions. However, it is suggested that prolonged ( $>$ three months) moisture susceptibility of pellets be determined in the future.

\section{Conclusions}

Various routes to prepared mechanically strong sodium silicate bonded pellets were explored here. It was found that the addition of non-source material $\mathrm{SiO}_{2}$ addition and the use of an alkaline activator facilitated geopolymerization of the $\mathrm{SiO}_{2}$ and $\mathrm{Al}_{2} \mathrm{O}_{3}$ contents present in the pelletization material, affording pellets with significant mechanical strength. Chromite pellets containing $3 \mathrm{wt} \%$ sodium silicate- $3 \mathrm{wt} \%$
$\mathrm{SiO}_{2}-1$ to $4 \mathrm{M} \mathrm{KOH}$ solution and cured at $75^{\circ} \mathrm{C}$ for $24 \mathrm{~h}$ had compressive strengths of between $2.56 \pm 0.44$ and $3.12 \pm 0.1$ $\mathrm{kN}$, exceeding the compressive strength $(1.54 \pm 0.5 \mathrm{kN})$ of pre-reduced pellets obtained from a South African $\mathrm{FeCr}$ producer. Furthermore, pellets cured at low temperatures did not indicate moisture susceptibility. This study presented a feasible approach to preparing cold-bonded chromite pellets without the need for high-temperature curing - occluding costs and environmental concerns relating to traditional pellet curing procedures. Further research is however required to optimize the proposed pelletization process. Additionally, a techno-economic study should be conducted in the future to assess the financial and practical viability of the proposed process.

\section{Acknowledgements}

The authors would like to thank the FeCr producer for supplying the chromite, BFD, and pre-reduced pellets used in this study, and Mr. Kosie Oosthuizen from the Geology Subject Group for the use of the pulverizer.

\section{References}

1. Haggerty SE. Oxide mineralogy of the upper mantle. Rev Mineral Geochem. 1991;25:355-416.

2. Paktunc A, Cabri L. A proton-and electron-microprobe study of gallium, nickel and zinc distribution in chromian spinel. Lithos. 1995;35(3-4):261-82. http://dx.doi.org/10.1016/00244937(95)99071-4.

3. Tathavakar VD, Antony M, Jha A. The physical chemistry of thermal decomposition of South African chromite minerals. Metall Mater Trans, B, Process Metall Mater Proc Sci. 2005;36(1):7584. http://dx.doi.org/10.1007/s11663-005-0008-1.

4. Beukes JP, Dawson NF, Van Zyl PG. Theoretical and practical aspects of $\mathrm{Cr}(\mathrm{VI})$ in the South African ferrochrome industry. J South Afr Inst Min Metall. 2010;110:743-50.

5. Kleynhans E, Beukes J, Van Zyl P, Fick J. Techno-economic feasibility of a pre-oxidation process to enhance prereduction of chromite. J South Afr Inst Min Metall. 2017;117(5):457-68. http://dx.doi.org/10.17159/2411-9717/2017/v117n5a8.

6. Murthy YR, Tripathy SK, Kumar CR. Chrome ore beneficiation challenges and opportunities: a review. Miner Eng. 2011;24(5):37580. http://dx.doi.org/10.1016/j.mineng.2010.12.001.

7. Gasik M. Handbook of ferroalloys: theory and technology. Oxford: Butterworth-Heinemann; 2013.

8. Basson J, Daavittila J. High carbon ferrochrome technology. In: Gasik M, editor. Handbook of ferroalloys: theory and technology. United Kingdom: Elsevier; 2013. Chapter 9. http:// dx.doi.org/10.1016/B978-0-08-097753-9.00009-5.

9. Gu F, Wills BA. Chromite: mineralogy and processing. Miner Eng. 1988;1(3):235-40. http://dx.doi.org/10.1016/08926875(88)90045-3.

10. Glastonbury RI, Van der Merwe W, Beukes JP, Van Zyl PG, Lachmann G, Steenkamp CJH, et al. Cr(VI) generation during sample preparation of solid samples: a chromite ore case study. Water SA. 2010;36(1):105-10. http://dx.doi.org/10.4314/wsa. v36i1.50913.

11. Riekkola-Vanhanen M. Finnish expert report on best available techniques in ferrochromium production. Helsinki: Finnish Environment Institute; 1999.

12. Kleynhans ELJ, Beukes JP, Van Zyl PG, Kestens PHI, Langa JM. Unique challenges of clay binders in a pelletised chromite pre-reduction process. Miner Eng. 2012;34:55-62. http://dx.doi. org/10.1016/j.mineng.2012.03.021. 
13. Gediga J, Russ M. Life cycle inventory (LCI) update of primary ferrochrome production. Paris: International Chromium Development Association; 2007.

14. Du Preez SP. Ferrochrome waste management: addressing current gaps. Potchefstroom, South Africa: North-West University; 2018.

15. Niemelä P, Krogerus H, Oikarinen P. Formation, characterization and utilization of CO-gas formed in ferrochrome smelting. In: 10th International Ferro-Alloys Congress (INFACON X); 2004; Cape Town, South Africa. Proceedings. Marshalltown, South Africa: South African Institute of Mining and Metallurgy; 2004. p. 68-77.

16. Glastonbury RI, Beukes JP, Van Zyl PG, Sadikit L, Jordaan A, Campbell Q, et al. Comparison of physical properties of oxidative sintered pellets produced with UG2 or metallurgicalgrade South African chromite: a case study. J South Afr Inst Min Metall. 2015;115(8):699-706. http://dx.doi.org/10.17159/24119717/2015/v115n8a6.

17. Kleynhans ELJ, Beukes JP, Van Zyl PG, Bunt JR, Nkosi NSB, Venter M. The effect of carbonaceous reductant selection on chromite pre-reduction. Metall Mater Trans, B, Process Metall Mater Proc Sci. 2017;48:827-40. http://dx.doi.org/10.1007/ s11663-016-0878-4

18. Iyengar M, Dutta S, Jana B, Awatramoni I, Saikia P. A new process for making iron ore pellets from hematite ore fines and/or from blue dust with cement as binder. Indian Patent No. 119163. 1968.

19. Svensson, J. The Grangcold Process. Steel Times; may 1969. p. 362 .

20. Lotosh V. Steaming iron-ore pellets. Steel in the USSR. 1973;3:450-2.

21. Lotosh V, Efimov A. Hardening of cement-binder pellets in a moist-air atmosphere at ordinary temperature. Steel in the USSR. 1973;3:169-71.

22. Eisele T, Kawatra S. A review of binders in iron ore pelletization. Miner Process Extr Metall Rev. 2003;24(1):1-90. http://dx.doi. org/10.1080/08827500306896.

23. Du Preez SP, Beukes JP, Van Zyl PG. Cr (VI) generation during flaring of co-rich off-gas from closed ferrochromium submerged arc furnaces. Metall Mater Trans, B, Process Metall Mater Proc Sci. 2015;46(2):1002-10. http://dx.doi.org/10.1007/ s11663-014-0244-3.

24. Beukes JP, Du Preez SP, Van Zyl PG, Paktunc D, Fabritius T, Päätalo $\mathrm{M}$, et al. Review of $\mathrm{Cr}(\mathrm{VI})$ environmental practices in the chromite mining and smelting industry - Relevance to development of the Ring of Fire, Canada. J Clean Prod. 2017;165:874-89. http://dx.doi.org/10.1016/j.jclepro.2017.07.176.

25. Du Preez SP. Cr (VI) generation during flaring of off-gas from closed ferrochromium submerged arc furnaces. Potchefstroom, South Africa: North-West University; 2014.

26. Du Preez SP, Beukes JP, Van Dalen WPJ, Van Zyl PG, Paktunc D, Loock-Hattingh MM. Aqueous solubility of Cr(VI) compounds in ferrochrome bag filter dust and the implications thereof. Water SA. 2017;43(2):298-309. http://dx.doi.org/10.4314/wsa. v43i2.13

27. Antony M, Tathavadkar V, Calvert C, Jha A. The soda-ash roasting of chromite ore processing residue for the reclamation of chromium. Metall Mater Trans, B, Process Metall Mater Proc Sci. 2001;32(6):987-95. http://dx.doi.org/10.1007/s11663-0010087-6.

28. Gericke WA. Environmental aspects of ferrochrome production. In: VII International Ferro-Alloys Congress; 1995; Trondheim, Norway. Trondheim: FFF; 1995. p. 131-140.

29. Zhou Y, Kawatra S. Humic substance-based binder in iron ore pelletization: a review. Miner Process Extr Metall Rev. 2017;38(5):321-37. http://dx.doi.org/10.1080/08827508.201 7.1328598
30. Halt J, Kawatra S. Review of organic binders for iron ore concentrate agglomeration. Miner Metall Process. 2014;31(2):7394.

31. Srivastava U, Kawatra SK, Eisele TC. Study of organic and inorganic binders on strength of iron oxide pellets. Metall Mater Trans, B, Process Metall Mater Proc Sci. 2013;44(4):1000-9. http://dx.doi.org/10.1007/s11663-013-9838-4.

32. Naiker O. The development and advantages of Xstrata's Premus Process. In: XI International Ferro-Alloys Congress; 2007; New Delhi, India. Proceedings. New Delhi: The Indian Ferro Alloy Producers' Association; 2007. p. 113-119.

33. Zambrano AP, Takano C, Mourao MB, Tagusagawa SY. Binder behavior on chromite-carbon composite pellets. Mater Res. 2016;19(6):1344-50. http://dx.doi.org/10.1590/1980-5373mr-2016-0264.

34. Du Preez SP, Beukes JP, Paktunc D, Van Zyl PG, Jordaan A. Recycling pre-oxidized chromite fines in the oxidative sintered pellet production process. J South Afr Inst Min Metall. 2019;119(2):207-15. http://dx.doi.org/10.17159/2411-9717/2019/ v119n2a13.

35. Van Staden Y, Beukes JP, Van Zyl PG, Du Toit JS, Dawson NF. Characterisation and liberation of chromium from fine ferrochrome waste materials. Miner Eng. 2014;56:112-20. http://dx.doi.org/10.1016/j.mineng.2013.11.004.

36. Jain P. Principles of foundry technology. New Delhi: Tata McGraw-Hill Education; 2003.

37. Neizel BW, Beukes JP, Van Zyl PG, Dawson NF. Why is $\mathrm{CaCO}_{3}$ not used as an additive in the pelletised chromite prereduction process? Miner Eng. 2013;45:115-20. http://dx.doi. org/10.1016/j.mineng.2013.02.015.

38. Kleynhans ELJ, Neizel BW, Beukes JP, Van Zyl PG. Utilisation of pre-oxidised ore in the pelletised chromite pre-reduction process. Miner Eng. 2016;92:114-24. http://dx.doi.org/10.1016/j. mineng.2016.03.005.

39. Subasri R, Näfe H. Phase evolution on heat treatment of sodium silicate water glass. J Non-Cryst Solids. 2008;354(10-11):896900. http://dx.doi.org/10.1016/j.jnoncrysol.2007.08.037.

40. Zhao B, Hayes P. Effects of oxidation on the microstructure and reduction of chromite pellets. In: 12 th International FerroAlloys Congress (INFACON XII); 2010; Helsinki, Finland. Proceedings. Helsinki: Outotec Oyj; 2010. p. 263-273.

41. Parappagoudar M, Pratihar D, Datta G. Neural network-based approaches for forward and reverse mappings of sodium silicate-bonded, carbon dioxide gas hardened moulding sand system. Mater Manuf Process. 2008;24(1):59-67. http://dx.doi. org/10.1080/10426910802543681.

42. Venkata Ramana M. Modelling of $\mathrm{CO}_{2}$ moulding process. Glob J Adv Eng Technol Sci. 2014;(spe):2277-6370.

43. Murthy IN, Babu NA, Rao JB. High carbon ferro chrome slag: alternative mould material for foundry industry. Procedia Environ Sci. 2016;35:597-609. http://dx.doi.org/10.1016/j. proenv.2016.07.046.

44. Rabbii A. Sodium silicate glass as an inorganic binder in foundry industry. Iran Polym J. 2001;10(4):229-35.

45. Davidovics M, Davidovits J, Orlinski J. Geopolymers form room temperature ceramic matrix. Materials and Processing Report. 1988;3(1):5. http://dx.doi.org/10.1080/08871949.198 8.11752155 .

46. Palomo A, Macias A, Blanco M, Puertas F. Physical, chemical and mechanical characterization of geopolymers. In: 9th International Congress on the Chemistry of Cement; 1992; New Delhi, India. Proceedings. New Delhi: National Council for Cement and Building Materials; 1992. p. 505-511.

47. Xu H, Van Deventer J. The geopolymerisation of alumino-silicate minerals. Int J Miner Process. 2000;59(3):247-66. http://dx.doi. org/10.1016/S0301-7516(99)00074-5.

48. Autef A, Joussein E, Gasgnier G, Rossignol S. Parameters that influence silica dissolution in alkaline media. In: Kriven WM, 
Gyekenyesi AL, Westin G, Wang J, Halbig M, Mathur S, editors. Developments in strategic materials and computational design III. Ohio: The American Ceramic Society; 2012. p. 13-24.

49. Swanepoel J, Strydom C. Utilisation of fly ash in a geopolymeric material. Appl Geochem. 2002;17(8):1143-8. http://dx.doi. org/10.1016/S0883-2927(02)00005-7.

50. Van Jaarsveld JGS, Van Deventer JSJ, Lorenzen L. The potential use of geopolymeric materials to immobilise toxic metals: part I. Theory and applications. Miner Eng. 1997;10(7):659-69. http://dx.doi.org/10.1016/S0892-6875(97)00046-0.

51. Van Jaarsveld JGS, Van Deventer JSJ, Lorenzen L. Factors affecting the immobilization of metals in geopolymerized flyash. Metall Mater Trans, B, Process Metall Mater Proc Sci. 1998;29(1):283-91. http://dx.doi.org/10.1007/s11663-9980032-z.

52. Van Jaarsveld JGS, Van Deventer JSJ, Schwartzman A. The potential use of geopolymeric materials to immobilise toxic metals: part II. Material and leaching characteristics. Miner Eng. 1999;12(1):75-91. http://dx.doi.org/10.1016/S08926875(98)00121-6.

53. Xu H, Van Deventer JS. Effect of source materials on geopolymerization. Ind Eng Chem Res. 2003;42(8):1698-706. http://dx.doi.org/10.1021/ie0206958.

54. Yang K-H, Song J-K, Ashour AF, Lee E-T. Properties of cementless mortars activated by sodium silicate. Constr Build Mater. 2008;22(9):1981-9. http://dx.doi.org/10.1016/j. conbuildmat.2007.07.003.

55. McCullough S, Barcza N, Hockaday S, Johnson C. Pre-reduction and smelting characteristics of Kazakhstan ore samples. In: 12th International Ferro-Alloys Congress (INFACON XII); 2010; Helsinki, Finland. Proceedings. Helsinki: Outotec Oyj; 2010.

56. Yu D, Paktunc D. Carbothermic reduction of chromite fluxed with aluminum spent potlining. Trans Nonferrous Met Soc China. 2019;29(1):200-12. http://dx.doi.org/10.1016/S10036326(18)64929-5.

57. Zhou M-F, Kerrich R. Morphology and composition of chromite in komatiites from the Belingwe greenstone belt, Zimbabwe. Can Mineral. 1992;30:303-17.

58. Hardjito D, Wallah SE, Sumajouw DM, Rangan BV. On the development of fly ash-based geopolymer concrete. Materials Journal. 2004;101:467-72.

59. Silva PD, Sagoe-Crenstil K, Sirivivatnanon V. Kinetics of geopolymerization: role of $\mathrm{Al}_{2} \mathrm{O}_{3}$ and $\mathrm{SiO}_{2}$. Cement
Concr Res. 2007;37(4):512-8. http://dx.doi.org/10.1016/j. cemconres.2007.01.003.

60. Lee WKW, Van Deventer JSJ. The effects of inorganic salt contamination on the strength and durability of geopolymers. Colloids Surf A Physicochem Eng Asp. 2002;211(2-3):115-26. http://dx.doi.org/10.1016/S0927-7757(02)00239-X.

61. Duxson P, Lukey GC, Separovic F, Van Deventer JSJ. Effect of alkali cations on aluminum incorporation in geopolymeric gels. Ind Eng Chem Res. 2005;44(4):832-9. http://dx.doi. org/10.1021/ie0494216.

62. Kirschner A, Harmuth H. Investigation of geopolymer binders with respect to their application for building materials. Ceram Silik. 2004;48:7-20.

63. Khale D, Chaudhary R. Mechanism of geopolymerization and factors influencing its development: a review. J Mater Sci. 2007;42(3):729-46. http://dx.doi.org/10.1007/s10853-0060401-4.

64. Du Preez SP, Beukes JP, Van Zyl PG, Tangstad M, Tiedt LR. Silicon carbide formation enhanced by in-situ-formed silicon nitride: an approach to capture thermal energy of co-rich offgas combustion. Metall Mater Trans, B. 2018;49(6):3151-63. http://dx.doi.org/10.1007/s11663-018-1413-6.

65. Duxson P, Provis JL, Lukey GC, Mallicoat SW, Kriven WM, Van Deventer JSJ. Understanding the relationship between geopolymer composition, microstructure and mechanical properties. Colloids Surf A Physicochem Eng Asp. 2005;269(13):47-58. http://dx.doi.org/10.1016/j.colsurfa.2005.06.060.

66. Nair BG, Zhao Q, Cooper RF. Geopolymer matrices with improved hydrothermal corrosion resistance for high-temperature applications. J Mater Sci. 2007;42(9):3083-91. http://dx.doi. org/10.1007/s10853-006-0526-5.

67. Rowles M, O'Connor B. Chemical optimisation of the compressive strength of aluminosilicate geopolymers synthesised by sodium silicate activation of metakaolinite. J Mater Chem. 2003;13(5):1161-5. http://dx.doi.org/10.1039/b212629j.

68. Schmücker M, MacKenzie KJD. Microstructure of sodium polysialate siloxo geopolymer. Ceram Int. 2005;31(3):433-7. http://dx.doi.org/10.1016/j.ceramint.2004.06.006.

69. Jina W, Zitian F, Xiaolei Z, Di P. Properties of sodium silicate bonded sand hardened by microwave heating. Res Dev. 2009;6:191-6. 